\title{
PENGOLAHAN SE'I BABI PADA KELOMPOK DARMA WANITA DI LINGKUNGAN PEMDA SABU RAIJUA.
}

\author{
Gemini E M Malelak ${ }^{1)}$, Geertuida M Sipahelut ${ }^{1)}$, Gusti A Y Lestari' ${ }^{1)}$, Martina Raga Lay ${ }^{2)}$ \\ 1. Fakultas Peternakan, Universitas Nusa Cendana \\ 2. Fakultas Ilmu Sosial dan Politik, Universitas Nusa Cendana \\ E-mail Korespodensi: geminimalelak@yahoo.com.au.
}

\begin{abstract}
ABSTRAK
Kegiatan pelatihan ini bertujuan untuk melatih peserta tentang pengolahan daging babi menjadi $s e^{\prime} i$ dimulai dengan cara pemilihan bahan baku, pemilihan bahan tambahan yang akan digunakan, proses pengolahan serta cara pengemasan yang baik. Materi pelatihan ini meliputi mengolah daging babi menjadi se'i ( isi, kulit dan rusuk) untuk menyediakan diversifikasi pangan keluarga dan menyemarakkan dunia kuliner di lingkungan Kabupaten Sabu Raijua (Sarai). Metode yang digunakan untuk mencapai tujuan tersebut di atas adalah melalui penyuluhan, praktek atau kegiatan percontohan cara pengolahan daging babi, kegiatan pendampingan dan evaluasi. Peserta pelatihan adalah ibu-ibu kelompok PKK Pemda Sabu Raijua. Pemilihan jenis ternak babi, pemilihan jenis bahan tambahan, cara pengolahan dan pengasapan se' $i$ babi adalah materi yang diberikan dalam kegiatan pelatihan ini. Hasil kerja pada kegiatan pendampingan dan evaluasi digunakan oleh tim PKK Kabupaten Sarai untuk menentukan kebijakan programprogram PKK selanjutnya serta program pelatihan pengolahan hasil ternak pada tahun-tahun berikutnya.
\end{abstract}

Kata kunci: $s e^{\prime} i$ isi, se' $i$ rusuk dan $s e$ ’ $i$ kulit, pelatihan 


\section{PENDAHULUAN}

Kabupaten Sabu Raijua (Sarai) merupakan salah satu Kabupaten yang baru terbentuk di Provinsi Nusa Tenggara Timur (NTT). Sebagai kabupaten baru, pemerintah daerah mulai membenahi semua sektor perekonomian di Kabupaten Sarai ini. Pengembangan potensi peternakan menjadi salah satu program pemerintahan Kabupaten Sarai, untuk mendorong peningkatan perekonomian masyarakat Sarai dan juga mendukung program pemerintah pusat dalam program swasembada pangan dalam hal ini daging.

Program pengembangan didunia peternakan, sebaiknya tidak hanya sampai pada menyediakan ternak dan daging segar saja, namun perlu diikuti dengan program pengolahan daging ataupun hasil ternak lainnya seperti kulit maupun feses untuk memberi nilai tambah bagi masyarakat. Pengembangan dunia pengolahan daging dapat memberi manfaat tidak hanya untuk diversifikasi pangan masyarakat namun dapat juga digunakan untuk memenuhi sektor wisata yaitu dengan menyediakan berbagai jenis kuliner bagi wisatawan.

Jenis ternak yang lasim dipelihara oleh masyarakat di Kabupaten Sarai adalah ternak domba dan ternak babi. Nilai ekonomis dari ternak-ternak tersebut masih rendah, disebabkan karena masyarakat hanya memelihara dalam jumlah sedikit karena hanya diperuntukkan untuk memenuhi konsumsi rumah tangga atau kebutuhan adat lainnya. Pemahaman tentang nilai guna ternak untuk mendukung perekonomian masyarakat belum terlalu dipahami secara baik.

Kegiatan pelatihan ini bertujuan untuk melatih masyarakat tentang cara-cara pengolahan daging, khususnya daging babi, dimulai dengan cara pemilihan bahan baku yang cocok untuk jenis olahan tertentu, pemilihan bahan tambahan yang akan digunakan, proses pengolahan serta cara pengemasan yang baik. Tujuan lainnya adalah untuk mengembangkan ketrampilan peserta agar peserta mampu berinovasi dalam mengolah hasil-hasil ternak dan kemudian akan terdorong untuk memulai usaha kuliner yang mempunyai peluang besar untuk dikembangkan di Kabupaten 
Sabu Raijua. Dengan berkembangnya usaha pengolahan hasil ternak dapat menyediakan variasi menu kuliner bagi pendatang di Kabupaten ini sehingga dapat mendukung sektor pariwisata. Diharapkan peserta dapat memanfaatkan bahan tambahan alami yang ada disekitar mereka dengan demikian akan mendorong berkembangnya subsektor pertanian maupun kelautan.

Adapun sasaran utama dari kegiatan pelatihan ini adalah kelompok perempuan yang tergabung sebagai Kelompok Darma Wanita lingkungan Pemda Sabu Raijua. Sasaran berikutnya adalah wirausaha perempuan atau ibu-ibu rumah tangga yang melakukan usaha mandiri.

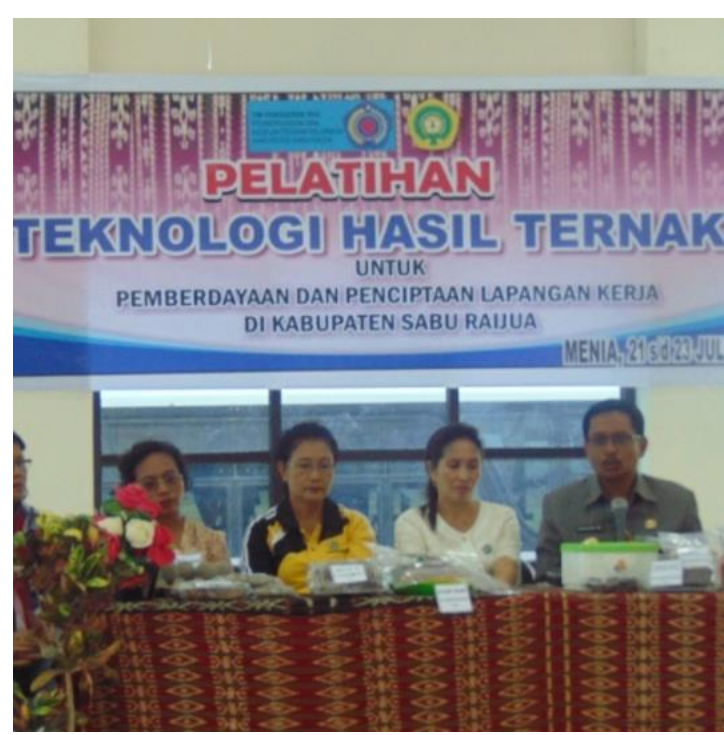

Gambar 1. Pembukaan oleh Bupati Sarai

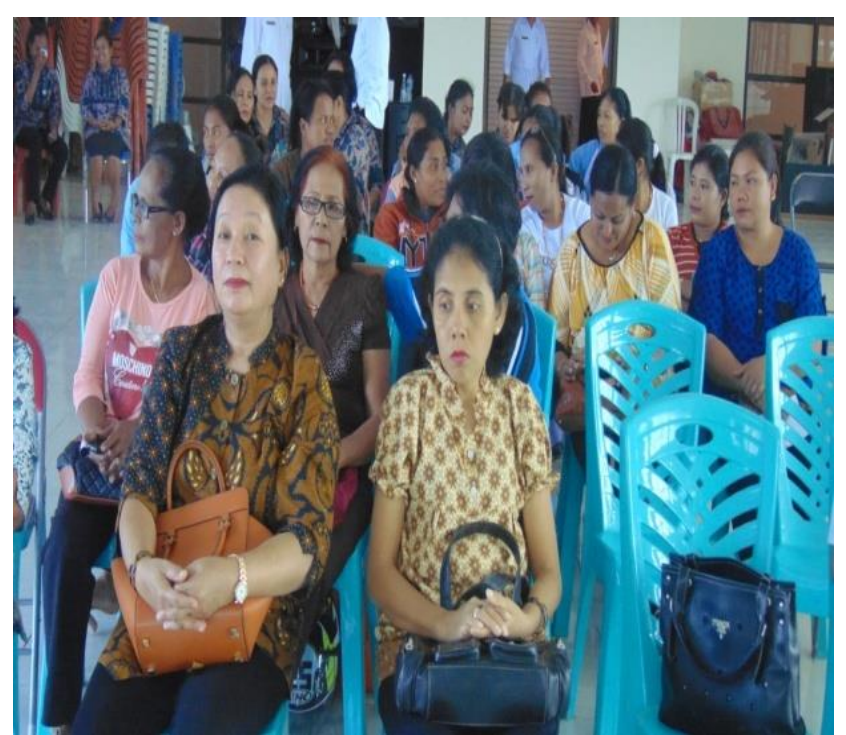

Gambar 2. Anggota PKK Peserta Pelatihan

Adapun luaran yang diharapkan dalam pelatihan ini adalah menghasilkan produk pangan dalam hal ini hasil olahan ternak yang sehat dan terjamin keamanannya bagi konsumen. Luaran lainnya adalah pelatihan ini dapat menghasilkan tenaga yang terampil untuk mengolah hasil ternak. 


\section{METODE PELAKSANAAN}

Metode yang digunakan untuk mencapai tujuan tersebut di atas adalah melalui kegiatan penyuluhan, kegiatan praktek atau kegiatan percontohan cara pengolahan daging babi, kegiatan pendampingan dan evaluasi. Kegiatan penyuluhan dan percontohan langsung dilakukan di Kabupaten Sarai yaitu di Kantor Bupati Sarai. Kegiatan pendampingan dan evaluasi dilakukan melalui media online karena letak Kabupaten Sarai yang cukup jauh dari Universitas Nusa Cendana. Telah disepakati bersama bahwa kegiatan pendampingan melalui konsultasi secara rutin terutama dengan ketua tim penggerak PKK, demikian juga dengan kegiatan evaluasi. $S e^{\prime} i$ babi dapat dibuat dalam 3 bentuk yaitu se' $i$ daging, se ' $i$ rusuk dan $s e^{\prime} i$ kulit. Ketiga jenis se' $i$ ini mempunyai segment pasar sendiri-sendiri dan dijual dengan harga yang berbeda. Pada prinsipnya proses pengolahan ketiga jenis $s e^{\prime} i$ ini adalah sama, namun perlu diperhatikan beberapa hal.

Hal-hal yang perlu diperhatikan dalam pengolahan se’ $i$ kulit babi adalah kandungan lemak pada kulit babi yang akan mempengaruhi bara pada saat pengasapan, karena lemak akan jatuh ke bara yang menyebabkan bara menjadi lebih panas dan lebih berasap. Sehingga pengontrolan selama pengasapan harus lebih teliti dibanding pada saat pengasapan se ’ $i$ isi dan se' $i$ rusuk.

Pada pengolahan se'i rusuk, perlu diperhatikan panas bara, karena ukuran rusuk yang besar dan agak mnelengkung, sehingga pada saat pengasapan harus lebih sering di bolak-balik agar tingkat kematangan merata. Selain panas bara, pada pengolahan se'i isi yang perlu diperhatikan adalah ukuran daging harus seragam, sehingga pada saat pengasapan dapat mencapai tingkat kematangan yang seragam.

Pada kegiatan penyuluhan diberikan pembekalan tentang ciri-ciri daging segar dan jenis daging serta bahan tambahan pangan yang dapat dipilih sesuai jenis olahan yang akan dibuat. Materi 
dalam penyuluhan ini ditekankan pada perbedaan penggunaan bumbu dan/atau bahan tambahan serta cara pengasapan pada pengolahan $s e^{\prime} i$ isi, se'i rusuk dan se' $i$ kulit.

Pada kegiatan pelatihan/ percontohan semua peserta secara berurutan melakukan proses pengolahan sesuai langkah-langkah yang telah dijelaskan pada materi yang diberikan oleh pelatih. Peserta diberikan hand-out materi tentang proses pengolahan se'i isi, se 'i rusuk dan se' $i$ kulit. Dalam kegiatan percontohan ini, pelatih hanya berfungsi sebagai pengarah, sedangkan peserta yang langsung terlibat dalam proses pengolahan tersebut.

Umumnya daging se 'i yang dihasilkan mempunyai rendemen antara $55-70 \%$. Semakin lama diasapi, se ’ $i$ babi semakin sedikit kadar air se’ $i$, dan semakin kecil rendemen yang didapat dan semakin tinggi harga jualnya. Untuk pengusaha se' $i$ Babi sebaiknya diatur rendemen untuk memperoleh keuntungan yang layak. Berikut ini adalah proses pengolahan se’ $i$ Babi.

$$
\text { Rendemen }=\frac{\text { Berat } S e^{\prime} i}{\text { Berat daging segar }} \times 100 \%
$$

\section{HASIL DAN PEMBAHASAN}

\section{Kegiatan Penyuluhan}

Kegiatan penyuluhan di lakukan di Kantor Bupati, Menia Kabupaten Sarai. Peserta adalah ibuibu kelompok PKK Pemda Sabu Raijua. Materi yang diberikan dalam penyuluhan ini adalah tentang keuntungan mengolah daging babi dibanding hanya dijual dalam bentuk segar. Salah satu produk olahan daging babi adalah se'i (daging asap). Produk olahan ini sangat terkenal di Kota Kupang dan sekitarnya dan merupakan salah satu makanan favorit untuk wisata kuliner. 
Oleh karena itu produk olahan ini perlu dikembangkan di seluruh daerah di NTT terutama untuk mengembangkan dunia kuliner di NTT.

Ada beberapa hal yang perlu diperhatikan dalam pengolahan se'i Babi. Pertama adalah pemilihan jenis ternak Babi yang sesuai untuk olahan se' $i$. Ternak babi kampung kurang cocok untuk digunakan dalam pengolahan $s e^{\prime} i$, karena proporsi daging dan lemak hampir sama banyak. Babi Duroc adalah jenis ternak babi yang cocok digunakan untuk se' $i$ karena proporsi dagingnya lebih banyak dibanding lemak, dan tekstur dagingnya lebih padat dibanding daging babi kampung.

Dalam pengolahan $s e^{\prime} i$ isi, daging yang diambil sebaiknya dipisahkan dari kulit karena pada saat pengasapan kulit dan daging mencapai tingkat kematangan dalam waktu yang berbeda.

Disamping itu kulit mengandung lebih banyak lemak sehingga pada saat pemeraman akan mengalami perubahan aroma yang lebih cepat dibanding daging.

Selain jenis babi, penggunaan kayu untuk pengasapan dan penggunaan bahan tambahan/ bumbu dalam pengolahan se' $i$ babi juga dijelaskan dalam penyuluhan ini. Pada saat pengasapan sebaiknya menggunakan jenis kayu keras tapi tidak bergetah. Kayu keras umumnya mengandung resin yang rendah dan menghasilkan bara api yang tahan lama. Kayu yang lasim digunakan dalam pengolahan se'i adalah kayu Kusambi (Schleichera oleosa) namun dapat dicampur dengan jenis kayu lainnya seperti kayu bidara ((Zizyphus mauritiana lamk), kayu jambu biji/ Kujawas Jambu biji ( Psidium guajava).

Penggunaan bumbu atau bahan tambahan dalam pengolahan $s e^{\prime} i$ babi sebaiknya ditambahkan dengan jeruk nipis untuk menetralisir rasa lemak yang kuat pada $s e^{\prime} i$ babi. Walaupun demikian ada juga konsumen yang menyukai rasa se'i yang agak berlemak. 
Widarti dkk (2012) melaporkan bahwa 50\%-70\% konsumen di Kota Kupang mengkonsumsi se'i dipengaruhi oleh faktor-faktor kesehatan, sifat fisiko-kimia dan harga. Adu (2017) melaporkan bahwa tingkat pencemaran se' $i$ dapat terjadi mulai dari pemilihan daging segar, saat pemberian bumbu bahkan setelah pengasapan. Oleh karena faktor higienitas dan rendemen perlu diperhatikan selama proses pengolahan se'i.

\section{Kegiatan Pelatihan/Percontohan}

Kegiatan pelatihan diberikan setelah penyuluhan. Pada kegiatan ini peserta diberikan handout tentanglangkah-langkah pengolahan $s e^{\prime} i$ isi, se 'i rusuk dan se' $i$ kulit. Instruktur hanya berfungsi sebagai pengarah. Dalam pelatihan ini masalah yang paling ditekankan adalah ukuran daging yang baik tepat, karena setelah proses pengasapan ukuran daging akan mengecil. Pemilihan jenis bumbu atau bahan tambahan juga perlu diperhatikan karena akan mempengaruhi warna, aroma dan rasa se'i.

Faktor lain yang perlu diperhatikan dalam pelatihan ini adalah cara pengasapan dan lama pengasapan. Jarak penempatan daging di atas permukaan bara selama pengasapan akan mempengaruhi lama pengasapan dan hal ini tentunya berhubungan dengan banyaknya bahan bakar yang diperlukan. Lama pengasapan juga akan mempengaruhi rendemen se'i. Menentukan tingkat kematangan se'i merupakan hal yang terakhir yang harus dipelajari oleh peserta pelatihan.

Pelatih menjelaskan tentang manfaat pemberian dan pemilihan bumbu atau bahan tambahan pangan dalam pengolahan $s e$ 'i, serta kelebihan maupun kekurangan dari penggunaan bumbu/ bahan tambahan tersebut. Peserta dianjurkan untuk menggunakan bumbu atau bahan tambahan yang lasim duigunakan dan yang selalu tersedia di daerah mereka, serta bisa berinovasi dengan menggunakan bahan tambahan lainnya untuk mengembangkan kualitas se' $i$ yang dihasilkan serta dapat memberi cirri khas pada produk yang mereka hasilkan. Sebagai contoh penggunaan rosela dan jeruk nipis dalam pengolahan se' $i$ sapi (Malelak dkk, 2017) dan jeruk purut (Malelak dkk, 2018) dapat diaplikasikan pada $s e^{\prime} i$ babi. 
Setelah pengasapan, peserta menghitung rendemen yang dihasilkan, serta menghitung jumlah pengeluaran selama proses produksi. Peserta diminta untuk menentukan harga jual yang pantas untuk produk mereka, berdasarkan perhitungan biaya produksi dan harga jual yang telah mereka tentukan. Dengan demikian, pada saat produksi, peserta dapat menentukan jumlah dan jenis bahan tambahan yang mereka gunakan, lama pengasapan yang normal, serta menentukan harga jual produknya.

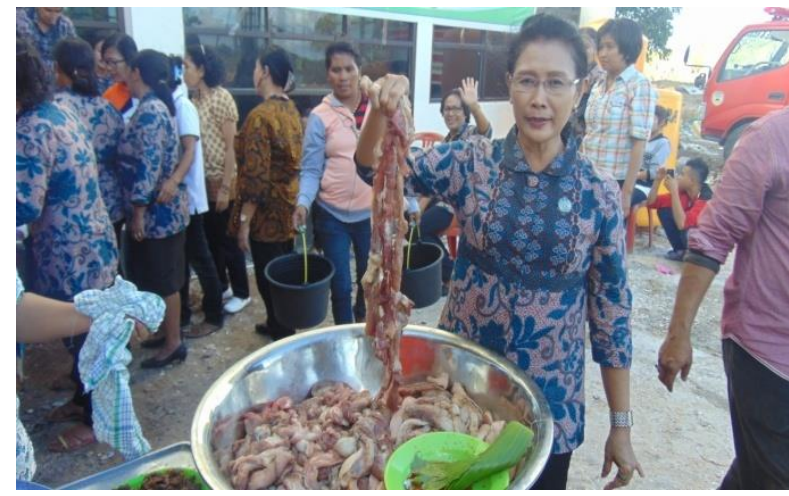

Gambar 3. Se'i isi babi

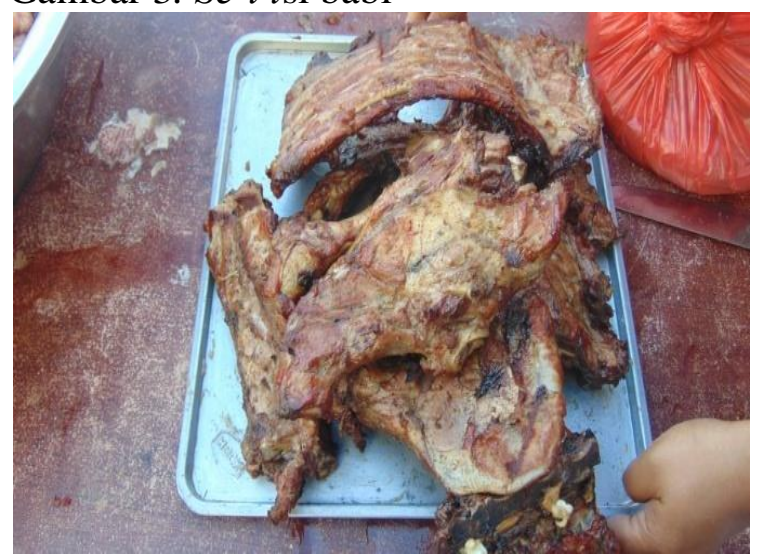

Gambar 5. Se’i rusuk babi

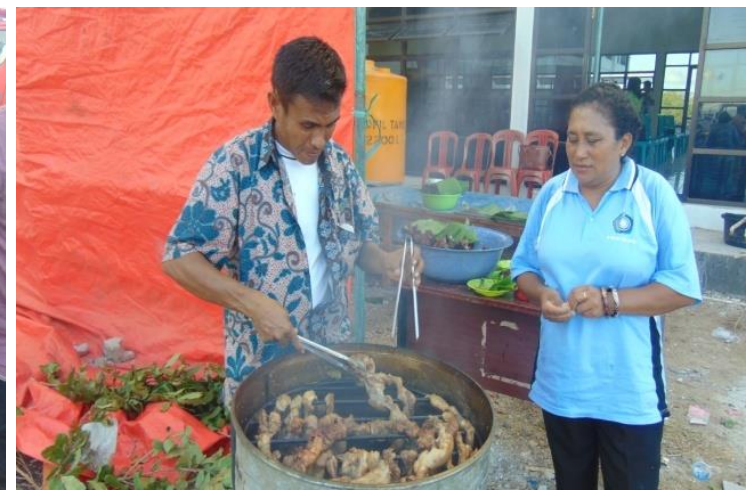

Gambar 4. Pengsapan se’i

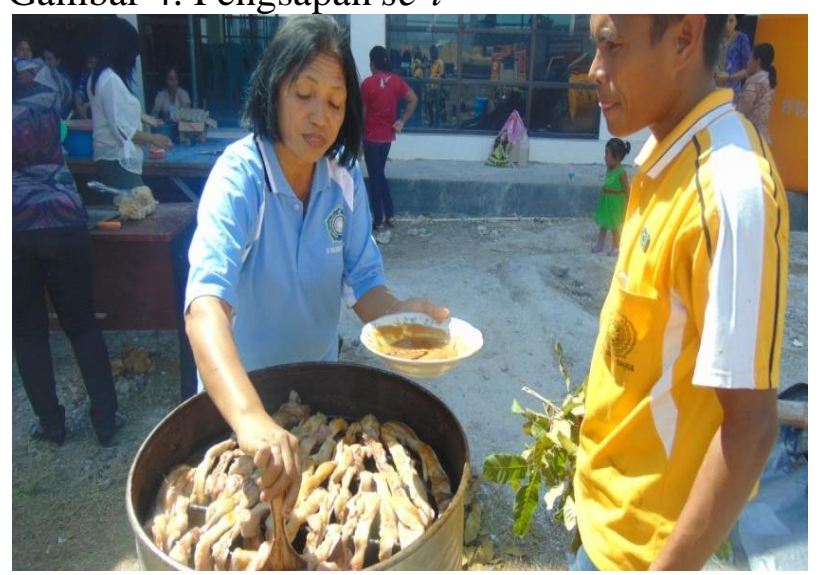

Gambar 6. Se' $i$ kulit babi

Dalam kegiatan pelatihan ini juga diberikan pengarahan tentang pentingnya kontrol sanitasi untuk menghasilkan se 'i yang higienis. Menurut Cruz dkk (2018) critical control point (CCP) yang 
harus diperhatikan dalam pengolahan se'i babi adalah penerimaan daging, pengirisan, pencampuran bumbu, pengasapan dan penyimpanan.

\section{Kegiatan Pendampingan}

Kegiatan pendampingan dilakukan oleh ketua dan wakil ketua tim PKK Pemda Sarai yaitu Ibu bupati dan ibu wakil bupati. Apabila ada masalah yang memerlukan pendapat tim pelaksana dari UNDANA, maka dikomunikasikan melalui email. Masalah yang sering didiskusikan adalah menyangkut cara pengasapan yang digunakan, apakah secara terbuka atau tertutup. Selama pelatihan cara pengasapan yang dilakukan adalah secara tertutup dengan menggunakan drum (Gambar 4 dan 6). Namun dalam pelaksanaannya fasilitas tersebut tidak tersedia sehingga dapat menggunakan cara pengasapan terbuka (tradisional), tanpa menggunakan drum.
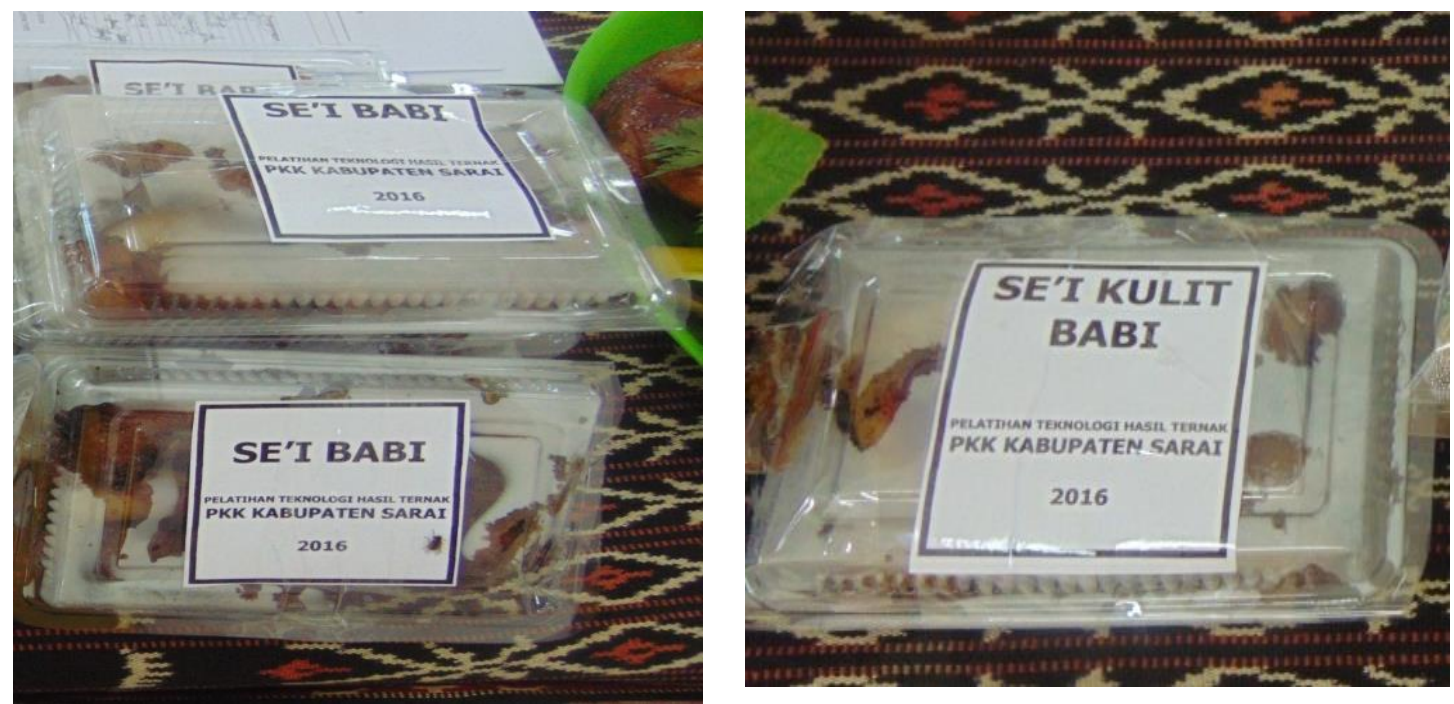

Gambar 7. Produk se 'i isi babi dan se'i kulit babi telah dikemas

Masalah kedua yang sering didiskusikan adalah penggunaan takaran pemberian bahan tambahan alami seperti jeruk nipis atau jeruk purut, karena hal ini akan mempengaruhi rasa. Keputusan takaran pemberian diserahkan pada produsen sesuai selera yang diinginkan, pelatih hanya 
memberi informasi tentang cara dan waktu pemberian, agar bahan tambahan yang digunakan memberi efek yang optimal.

\section{Kegiatan Evaluasi}

Kegiatan evaluasi juga dilakukan oleh ketua dan wakil ketua tim PKK Pemda Sarai yaitu Ibu bupati dan ibu wakil bupati. Hasil evaluasi didiskusi dengan tim pelatih dari UNDANA untuk melihat hasil kerja dari anggota kelompok yang dilatih. Hasil evaluasi dijadikan acuan untuk pembuatan program pemberdayaan perempuan yang merupakan anggota tim PKK Pemda Sarai pada tahun anggaran berikutnya.

\section{KESIMPULAN DAN SARAN}

Dari hasil yang dilakukan didapati bahwa peserta tertarik untuk mengembangkan usaha pengolahan se' $i$ babi, namun karena daya beli masyarakat yang rendah, usaha ini tidak dapat dilakukan secara kontinyu setiap hari. Peserta hanya mengandalkan pesanan baik untuk acaraacara selamatan maupun sebagai oleh-oleh.

Disarankan untuk kegiatan pengolahan dapat melihat kemungkinan pemasaran ke luar Kabupaten sarai, dengan menambah ciri khas produk se'i babi yang dihasilkan. Promosi wisata Kabupaten Sarai dapat memicu berkembangnya usaha pengolahan se'i sebagai jenis kuliner yang dapat ditawarkan pada wisatawan.

\section{UCAPAN TERIMA KASIH}

Ucapan terimakasih yang sebanyak-banyaknya untuk Bapak Bupati dan ibu bupati sebagai Ketua tim PKK Kabupaten Sabu Raijua yang telah membiayai dan memfasilitasi kegiatan pelatihan pengolahan hasil ternak ini. 


\section{DAFTAR PUSTAKA}

Adu, A. (2017). Perbedaan jumlah mikroba yang mencemari daging se'i selama proses pengolahan antara perusahaan pengolahan daging se'i sapi moderen dan tradisional di kota kupang. Media Kesehatan Masyarakat 2(2): 96-107

Cruz, E.S.D.C., Lalel, H.J.D., \& Kale, P.R. (2018). Evaluasi penerapan hazard analysis critical control point (HACCP) pada mutu daging se'i babi di Kota Kupang. Jurnal Peternakan Indonesia 20 (3):201-210.

Malelak, G.E.M., Lalel, H.J.D., Kale, P.R., \& Jelantik, I.G.N.( 2017). The Sensory Properties, Color, Microbial, Lipid Oxidation, and Residual Nitrite of Se'i Marinated with Lime and Roselle Calyces Extracts. Media Peternakan. 40(3):194-201. http://medpet.journal.ipb.ac. $\mathrm{id} /$

Malelak, G.E.M., Kale, P.R., \& Armadianto H. (2018). Kandungan air, protein dan lemak pada se'i sapi yang diberi ekstrak jeruk purut (Cytrus hystrix). Prosiding Seminar Nasional FAPET IV. http://docrepository.undana.ac.id/index.php?p=showdetail\&id $=14125 \&$ keywords $=$ malelak

Widarti, S.S., Purnomo, H., \& Rosyidi, Dj. (2012). Studi Tentang Preferensi Konsumen, Sifat Fisiko Kimia dan Nilai Organoleptik Se ’i Daging Babi asal Kupang (Nusa Tenggara Timur). Sains Peternakan 10 (1): 23-29 